DOI: $10.15503 /$ jecs20162.199.216

\title{
DIFFERENT PERSPECTIVES ON THE USE OF L1 INTEACHING ENGLISH TO THE ELDERLY
}

\author{
AGATA SŁOWIK \\ Faculty of Letters, University of Wrocław, \\ (9) $\odot \Theta \Theta$ \\ Świętochowskiego 3/1, 51-606 Wrocław, Poland \\ E-mail address: slowik.agatha@gmail.com
}

\begin{abstract}
Own-language use has commonly been discouraged by language teachers worldwide ever since the Grammar Translation method gave place to other methods. In the last decade, however, there has been a visible shift in the use of mother tongue and, what is notable, an increasing number of methodologists have begun to point that the use of students' mother tongue may in fact facilitate the process of learning. Despite the long awaited return of own-language use students' learning preferences regarding the use of L1 are still often dismissed by teachers either due to lack of experience or to some reservations. Such attitudes may be especially harmful to a group which often demands own-language use in the classroom environment and which remains understudied - the elderly.

Therefore, the primary objective of the proposed paper is to highlight the differences between various teacher perceptions of whether or not own-language use does facilitate the process of older adult students' learning and to collate them with older adult students' own answers. The secondary objective is to present a possibly wide spectrum of various views reflecting the issues connected with the use of students' own language and the related influence of teachers' experiences and perceptions. The disparity between the answers provided by inexperienced teachers, experienced teachers and the elderly learners, especially while taking into account the use of students' L1, is aimed at drawing some conclusions that may point to alternative directions in the future studies of own-language use in the classroom environment.
\end{abstract}

Key words: seniors, language teaching, teacher perceptions, L1 in English teaching

\section{INTRODUCTION}

The primary objective of this article ${ }^{1}$ is, therefore, to highlight the differences between various teacher perceptions of whether or not own-language use assists the progress of Older Adult Students' (OA) learning and to col-

1 Some of the data and conclusions included in the following paper are based on the article which will be published in: Stowik, A. (2016). Adult Learners and the Use of L1 in the Foreign Language Classroom. Anglica Wratislaviensia, 54. [in print]. Therefore, the aforementioned article is a continuation and a wider study of the issue of the use of L1 in teaching English to the elderly, this time concentrating more on the differences between students and teachers' perspectives. 
late them with OA's own answers. It is also an attempt to present a possibly wide spectrum of various views reflecting the issues connected with the use of students' own-language. Moreover, the disparity between the answers provided by inexperienced teachers (IT), experienced teachers (ET) and the older adult learners, especially while taking into account the use of students' L1, is aimed at drawing some conclusions for future studies. In fact, nearly thirty years ago David Battersby (1987) noted that "there has always been a reluctance among adult educators to examine the principles and practices of teaching and learning as they might apply to the elderly" (p. 4). This lack of focus on the older adult learner is beginning to change but the research on OA students' learning needs and preferences is still very scarce.

Ever since grammar-translation method gave place to other methods and teaching techniques students' mother tongue has been excluded from the language classrooms. Indeed, the belief that the best effects can be achieved while using Foreign Language only, has been a prevailing one for the past few decades. It has been especially harmful to teachers who, on the one hand, have either followed the new trend unconditionally or at least tried to do so, but at the same time often, if possible, had to incorporate their students' L1 into a lesson to make it more comprehensible. Recent studies (G. Cook, 2010; Vermes 2010; O'Keeffe, 2011; Kerr, 2011; Sampson, 2012; Levine, 2014) have shown not only that there has been an ongoing practice of using students' mother tongues in the language classrooms, but that teachers throughout the world have been in a way denying it. There are some articles written in support of the use of L1 as early as in the 1980s (Titford, \& Hieke, 1985; Edge, 1986; Atkinson, 1987; Alexander, 1987; Murphy, 1988; Heltai, 1989), but these are rather rare.

Kerr (2011) notes that the English teaching discourse "is beginning to shift" and points out that, "[...] with a massive growth in English language teaching provision around the world and with a growing awareness of the global nature of English as a lingua franca, native-speakers are starting to lose their authority over both the language and methodologies for teaching it. The experiential knowledge base has shifted, with an unsurprising refocussing of interest on translation." Along the same lines, Cook G. (2010) argues that, "translating should be a major aim and means of language learning, and a major measure of success" (xv). Similarly, according to Cunningham (2000, p. 2), “[...] recent articles argue that there is no reason why translation activities cannot be incorporated into a communicatively based lesson, [...] as they promote different activities that suit the different goals and aims of students". However, despite many arguments in support of the use of translation, there are hardly any publications devoted to the issue of own-language use from the students' perspective and no publications analysing OA students' opinions ${ }^{2}$.

2 Hall \& Cook (2013) provide a thorough analysis of the use of L1 in the language classroom. However, even though they present their finding based on 2,785 teachers working in 111 countries with two levels A1-A2+ (56.1\%) and B1-C1 (43.9\%). The students they focused on are divided into five age groups, as follows: 0-5 years old (1.2\%), 6-11 (19.2\%), 12-17 (35.6\%), 18-23 $(27.6 \%)$, and $24+(16.4 \%)$. Yet, the last group, which is as rich and as difficult to define as the ones concerned with younger adult students is treated as a separate category. 


\section{OLDER ADULT STUDENTS}

According to World Health Organisation the group of older adults is divided into four subgroups: 45-59 - pre-old, middle-age, immobile age, non-mobility age; 60-74 - young-old; 75-89 - old-old; 90 and more - oldest-old or longlife. Various scholars also define this group in different ways: e.g. Homstad (1987) as over forty, Snow and Hoefnagel-Hohle (1978) and Patkowski (1982) as 50 and more; Brown (1985) as 55 and more; Weinstein-Shr as a person from 40 to 65 years old and more (1993, p. 1); Wilson as those above the age of seventy (2008, p. 14); and Jaroszewska (2013a) as 50 and more. For the purpose of this research, adult learners will be treated as $50+$. The distinction is based on the courses offered by language schools and projects financed by EU, as that is where and how the subjects of this study learn English.

In recent years we have been observing many dynamic social, culturaland economic changes, which are linked to, among other things, a falling birth rate $(-0,4 \%$ as of 2014 , according to Central Statistical Office of Poland) and the simultaneous lengthening of human lifespan (according to EUROSTAT as of 07.12.2015, only in the years 1995-2013 the average length of life in the world increased by $4.5 \mathrm{pp}$ and in Poland by 5.1pp). Indeed, ageing is a worldwide phenomenon. That is why an increasing number of older adult students are interested in developing their linguistic, competences. This is often possible thanks to different local and international learning programmes for older adult students, Third Age Universities or private language schools, which ensure further education for 50+ learners. Latterly, there has been a growing interest in teaching older adult students not only due to the higher percentage of this group in the overall population, but also the increasing need to continue the intellectual development and the upsurge in the popularity of lifelong learning courses. Moreover, the international migration between the countries belonging to the European Union in a way forces older adults to learn new languages to develop their linguistic and intercultural competences, which will allow them to communicate with their friends and family members living abroad.

However, despite the growing interest of older adult students in lifelong learning this field remains understudied. Along the same lines, Cox (2014) notes that it still requires more attention as according to Singleton \& Ryan "in Poland (...) foreign languages are the third most popular field of study for older adults" (p. 91).

\section{RESEARCH DESIGN}

This project is based on two methods of collecting the data - a short interview and a questionnaire, which prove to be the most reliable methods of obtaining student feedback. Both the discussion and the survey complement one another: the interview helps to present the most important information concerning research subjects (older adult students' age, sex, occu- 
pation, reasons for studying the language and their learning background), whereas the questionnaire concentrates more specifically on how, when and why the older adult learners use their mother tongue in the classroom. The survey also helps to present the data linked to older adults'learning abilities, needs and practices (see Appendix 1). Both research instruments help to collect the data which will be later used in the following analysis. The questionnaire and the interview with the students were carried out in Polish to make sure that students could concentrate on the answers and not on any possible linguistic problems, whereas teachers answered the same questions in English.

\section{RESEARCH AIMS}

Both students and teachers previous learning (and teaching) experiences and personal theories often have an influence on what they expect of a language course. In the case of older adult students it seems that the importance of own-language use is among one of the most common beliefs influencing students' overall performance. This study concentrates on analysing to what extent the use of L1might facilitate the process of older adults' learning and what might be the reasons behind the use of their mother tongue from the students' perspective. The research also concentrates on collating students' own answers with the answers of two groups of teachers - a group experienced in teaching the elderly and a group without any previous teaching practice. The following research questions are investigated to address the above mentioned issues:

1. What is the teacher's perception of the importance of the use of L1 for the OA students?

2. When, if at all, would the OA students like to use their L1?

3. When would the OA students use their L1 in the lesson?

4. Are there any differences between the two groups (A1 and A2+) and what might be the reasons?

5. Does using L1 meet OA students' expectations of what the lesson should look like?

6. Do the students experience L1 interference and does it have an effect on their learning process?

7. Are there any possible drawbacks?

Both the students and the teachers were asked to answer the research questions connected to their learning preferences and personal beliefs as well as their previous learning and teaching practice. The results of the survey are presented below. 


\section{PARTICIPANTS}

There were four groups that took part in the research-OA students level CEFR A1 and A2+, ETs and ITs. Both OA students' groups consisted of 3 men and 18 women, in the group of inexperienced teachers there were 16 women and no men, whereas experienced teachers comprised 6 men and 6 women. Together, there were 49 subjects that took part in the experiment. In the groups of OAs the youngest person was 50 and the oldest 83 .

Table 1. Numbers and divisions of students in the groups

\begin{tabular}{|l|c|c|c|}
\hline & men & women & total \\
\hline OA A1 (beginner) & 2 & 8 & $\mathbf{1 0}$ \\
\hline OA A2+ (pre-intermediate) & 1 & 10 & $\mathbf{1 1}$ \\
\hline Inexperiencedteachers & 0 & 16 & $\mathbf{1 6}$ \\
\hline Experiencedteachers & 6 & 6 & $\mathbf{1 2}$ \\
\hline & $\mathbf{9}$ & $\mathbf{4 0}$ & $\mathbf{4 9}$ \\
\hline
\end{tabular}

Source: Own research

\section{Older Adult Learners (OA A1)}

There were many different professions in the group of older adults varying from accountants (3) and language teachers (2) to building contractors (1), journalists (1) and writers (1). There was also a nurse, a cashier, a lawyer, an architect, a manager, a secretary, as well as 4 pensioners and 3 people who decided not to reveal their professional backgrounds.

The subjects in this group were interested in learning English primarily because they found it necessary to learn English in order to communicate with their children and grandchildren who left the country and often live abroad with their English-speaking partners (7), as well as to get to know the culture of the countries in which they live (3). Therefore, learning the language in order to communicate with their families has become a crucial element of their motivation, which can be classified as integrative. Another reason for learning was the need to socialise (3), to keep in touch with their English speaking friends (1), to participate in activities similar to the ones enjoyed by the younger members of their families (3) and to make sure that they still exercise their brains and are exposed to challenging and useful activities (1). Moreover, older adults found it difficult to use computers and browse the Internet (2) without the knowledge of English, which they also found useful to communicate at work $(1)^{3}$.

\section{Experienced Teachers (ET)}

The group of experienced teachers consisted of 12 subjects -6 men and 6 women. All of the teachers had at least three years of previous experience in

3 For a more detailed analysis of Older Adult needs and reasons for learning languages see Jaroszewska (2013a) 
teaching English to the elderly as part of the EU project for students 50+. The teachers were 25-43 years old. All of the subjects have international teaching qualifications - Cambridge certificates and diplomas (CELTA and Delta, respectively).

\section{Inexperienced Teachers (IT)}

The group of inexperienced teachers comprises 16 pre-service female teachers, who are third year students in the Institute of English Studies at the University of Wrocław. All of the students are completing their teacher training course and do not have any teaching experience except for the mandatory teaching practice as part of their curriculum. The subjects have also never had any experience in teaching older adult students and claim not to know any older people who learn languages and continue their education.

\section{The research instrument ${ }^{4}$}

The two methods, which were used to collect the data - an interview and a questionnaire - were based on the survey designed by Hall and Cook (2013), which explores global practices and attitudes to own-language use in ELT. This paper, however, examines the issue not from the perspective of an English teacher dealing with students $24+$, but rather that of an older adult student and his/her teacher. Moreover, as recent studies on the use of L1 have been based primarily on school-age students and adults (grouped together as 24+), this study concentrates on older adult learners' need to resort to the mother tongue in the classroom and opinions presented by two groups experienced and inexperienced teachers. Such juxtaposition may show whether teachers, who are not formally trained in any way to teach older adult students can anticipate their students' needs and expectations and whether some experience of teaching other age groups can be useful while teaching OAs, or perhaps the contrary is the case.

\section{PRESENTATION AND INTERPRETATION OF THE RESULTS}

Once again the questions of the survey were divided into three groups: first, asking about OA students preferences regarding the use of L1 in the classroom; second, concentrating on students experiences in relation to own-language use; third, trying to obtain feedback on students personal opinions connected to the benefits and potential drawbacks resulting from resorting to their mother tongue in the classroom environment. The same questions were also asked to two groups of teachers.

4 The same questionnaire and the graphs regarding OAs answers are included in the already mentioned article, see Słowik (2016). 
Journal of Education Culture and Society No. 2_2016

The first group of results presented below illustrates students' answers to the following question:

\section{When would you like your L1 to be used in class?}

1. To explain vocabulary

2. To give instructions

3. To explain grammar

4. To correct spoken errors

5. To explain unclear meanings

6. To give feedback on written work

7. To test and assess

8. To maintain discipline

9. To develop rapport
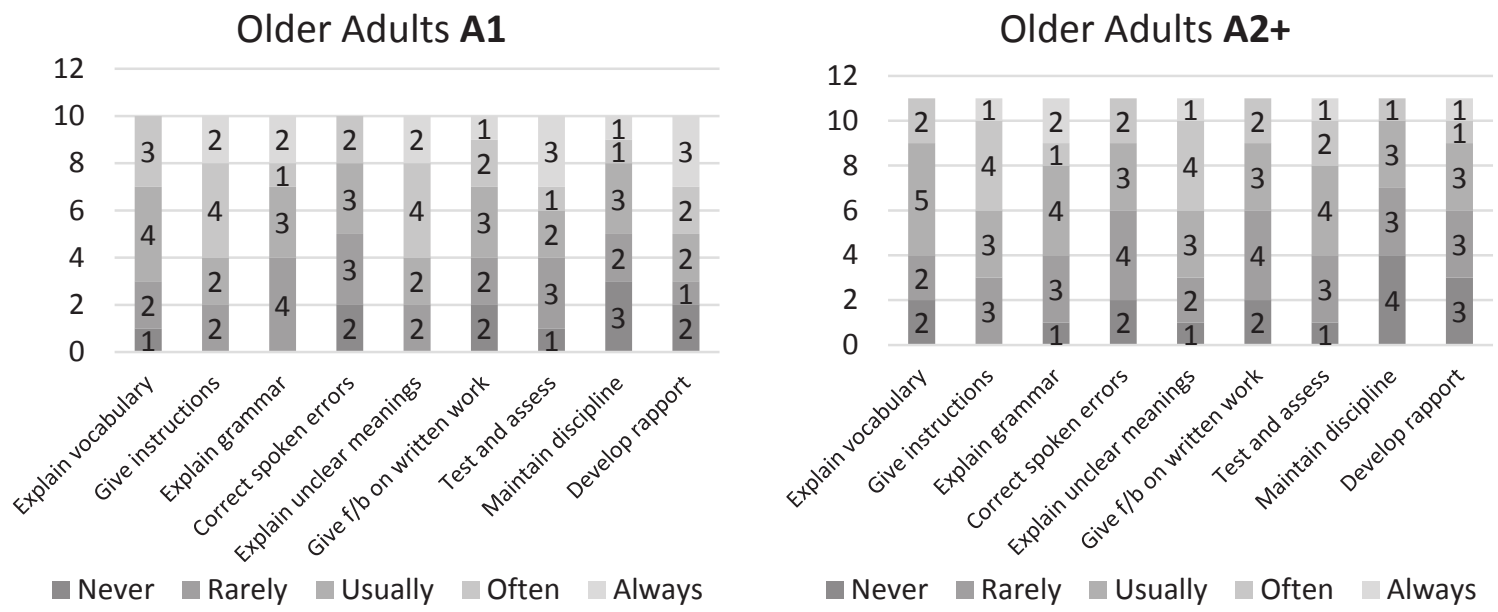

Figure 1. Adult learners' preferences regarding the use of L1

When would your students like their L1 to be used in class? 
OA A1 - ET's answers

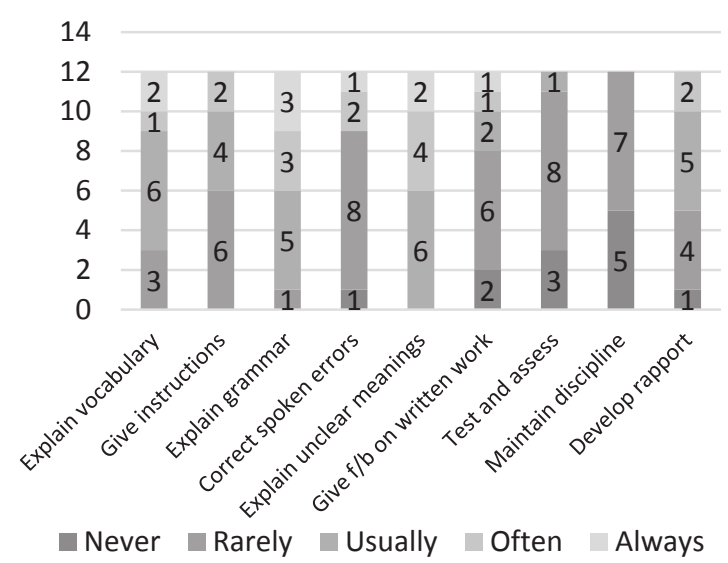

\section{OA A1 - IT's answers}

$$
20
$$
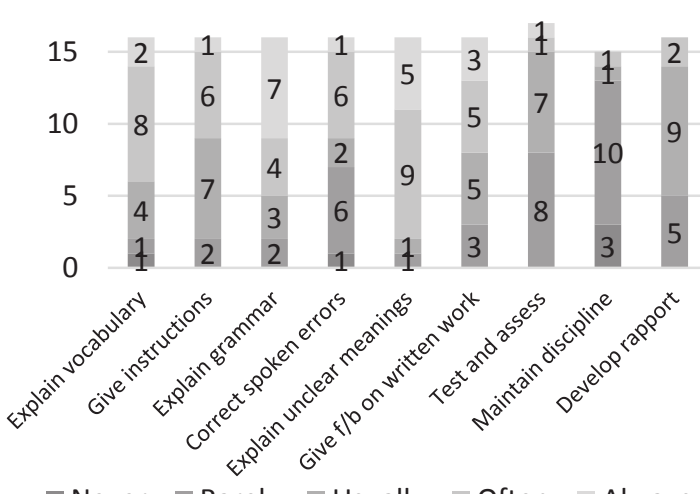

Never Rarely $\square$ Usually $\square$ Often Always
OA A2+ ET's answers

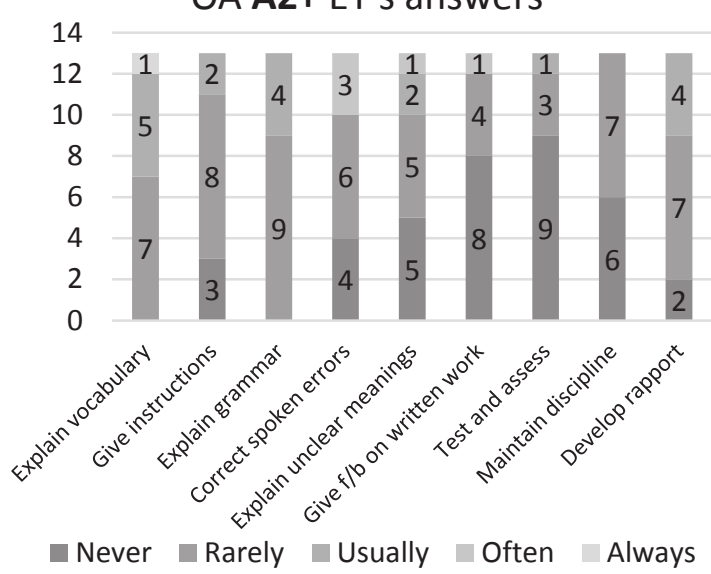

OA A2+ IT's answers

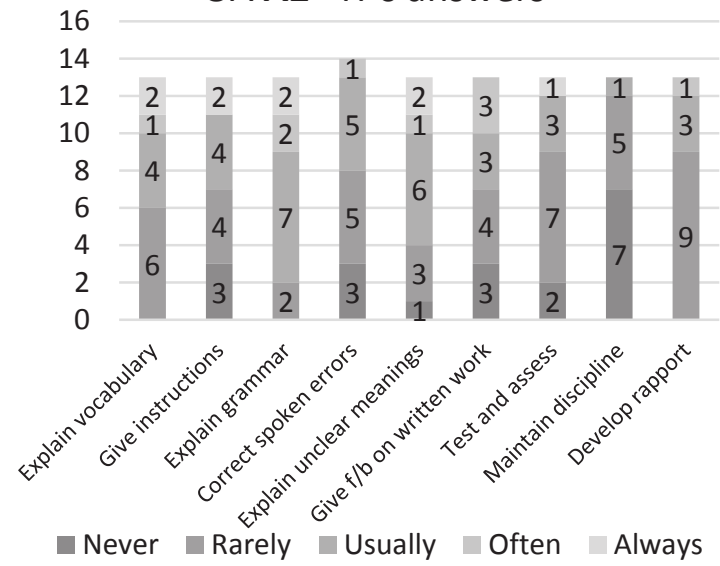

Figure 2. Teachers' opinions regarding OAs' preferences.

The results are also collected below and presented as percentages to make drawing conclusions easier.

Table 2. The overall percentage of students' and teachers' needs

\begin{tabular}{|l|c|c|c|}
\hline \% & OA A1 & ET A1 & IT A1 \\
\hline NEVER & $\mathbf{1 2}$ & $\mathbf{1 0}$ & 35 \\
\hline RARELY & 23 & 37 & 26 \\
\hline USUALLY & $\mathbf{2 6}$ & $\mathbf{2 5}$ & $\mathbf{2 7}$ \\
\hline OFTEN & 22 & 13 & 29 \\
\hline ALWAYS & $\mathbf{1 6}$ & $\mathbf{1 5}$ & $\mathbf{1 4}$ \\
\hline
\end{tabular}

\begin{tabular}{|l|c|c|c|}
\hline \% & OA A2+ & ET A2+ & IT A2+ \\
\hline NEVER & $\mathbf{1 6}$ & 32 & $\mathbf{1 6}$ \\
\hline RARELY & 27 & 48 & 38 \\
\hline USUALLY & $\mathbf{3 1}$ & 15 & $\mathbf{3 1}$ \\
\hline OFTEN & 19 & 4 & 8 \\
\hline ALWAYS & $\mathbf{6}$ & 1 & $\mathbf{8}$ \\
\hline
\end{tabular}

Source: Own research 
As can be seen from the graphs and the table above the answers provided by students and teachers are in many cases very different. There are, however, also some similarities. Older Adult students in the elementary group seem to believe that using their mother tongue in the classroom environment can be useful especially while developing rapport and during testing and assessing, whereas the pre-intermediate group is of the opinion that explaining grammar in Polish can help understand, maximum 3 and 2 answers always, respectively. On the other hand the most negative attitudes towards own-language use were expressed by OAs towards maintaining discipline 3 and 4 answers never in both groups. Which is interesting, experienced teachers seem to be of the opinion that explaining grammar, vocabulary and unclear meanings to elementary OA students should be done always in case of lower levels, 3 and 2 answers, however, OA A2+ may find it necessary to resort to their L1 only while explaining vocabulary -1 answer always. Inexperienced teachers seem to anticipate the problems more intuitively and 7 and 5 answers always are given to explaining grammar and unclear meanings, but at the same time in case of the stronger group they believe that they would need to use their mother tongue more often than the subjects themselves claim to be necessary - 2 answers always are given to explaining vocabulary, grammar, unclear meanings and giving instructions. All of these answers point to Wilkin's claim that, "[...] without grammar very little can be conveyed, without vocabulary nothing can be conveyed," (as cited in Singleton 1999, p. 3 ), which explains why students (and teachers) feel that it is crucial to ensure good understanding of lexis.

The aforementioned examples might point to the fact that inexperienced teachers try to base their opinions on their own learning experiences and try to apply that model to teaching older adult students. At the same time, while looking at the answers grouped together in the table above, it is clearly visible that inexperienced teachers more intuitive answers seem to be extremely close to, or even the same as, students own answers, whereas experienced teachers had a completely different view regarding older adults' needs. All three groups - A1 students, ETs and ITs agree that using L1 in the language classroom should be done usually and always, which means that mother tongue is a useful tool helping students understand and communicate ${ }^{5}$. The needs of the stronger group of older adults, on the other hand, have been completely misinterpreted by the experienced teachers (their answers are very far from the original statements provided by OAs). The most similar answers were given in case of the extremities always and never and in the most neutral position of usually. In all of the remaining points the answers are rather random.

On the whole, older adults are rather keen on using their L1 in the language classroom and they are willing to that rather often. Yet, the experienced teachers are more strict when it comes to own-language use and

5 For a comparison of younger adults' $18-49$ and older adults' 50+ views regarding the use of L1 in the language classroom, see Słowik (2016). 
would prefer to do that rarely 37 and $48 \%$ of the answers, OA A1 and OA $\mathrm{A} 2+$, respectively, or usually $25 \%$ (OA A1) and never $32 \%$ (OA A2+). Inexperienced teachers were more positive about the use of L1 as there were more answers usually 27 and 31\% in both OA groups, but there were also many more negative answers 35 and $16 \%$ of never in OA A1 and OA A2+, and rarely 26 and 38\%, A1 and A2+, respectively. These answers point to a certain incongruity. It seems that both groups of teachers are not sure of their students' needs and expectations regardless their teaching practice. Some expectations are shared by the students and teachers but there are hardly any regularities.

\section{The second part of the questionnaire concentrated on students' expo- sure to L1 during the lesson.}

The following graphs reflect students' experiences of the use of L1 in the language classroom and are answers to the question included below:

When do you use your L1 in class?

1. Check words in a bilingual dictionary

2. Compare English grammar to the grammar of your own language

3. Discuss tasks with your partner

4. Translate difficult grammar or lexis

5. Make sure you understand the instructions

6. Prepare for tasks first in L1 then in English

7. Ask questions

8. Ask for clarification

L1 Usage OA A1 and A2+

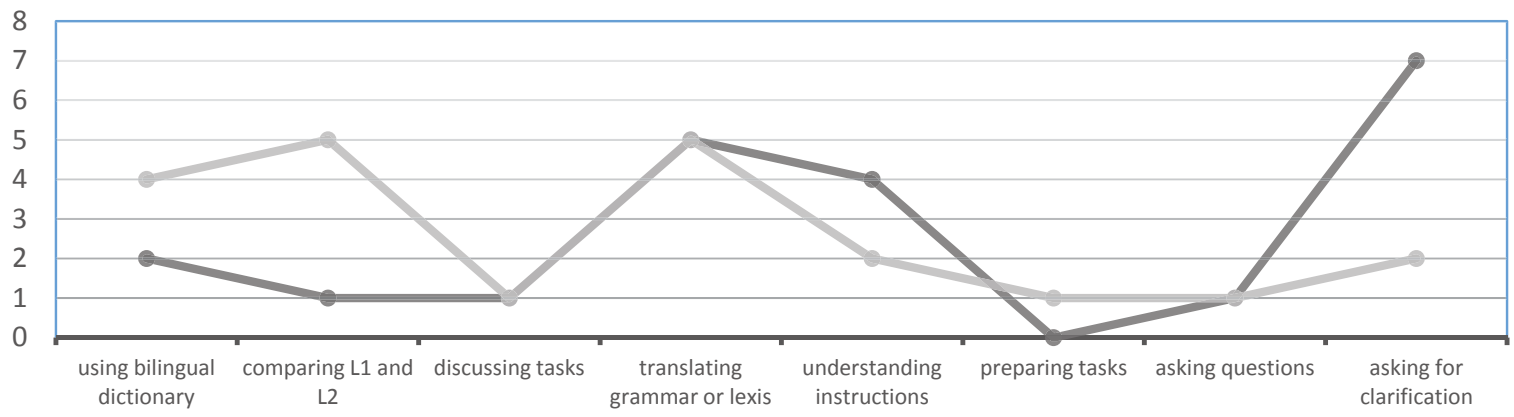

Figure 3. The number of responses of older adult learners' experience of using L1

When do/would your students use their L1 in class? 


\section{OA A1 and A2+ IT's answers}
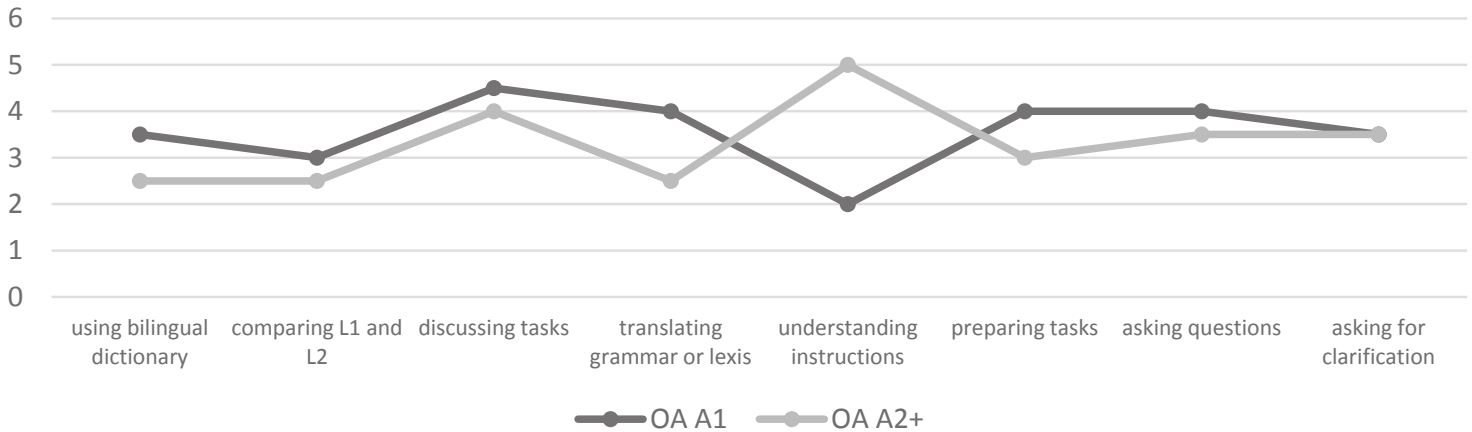

$\mathrm{OA} A 1$ and $\mathrm{A} 2+\mathrm{ET}$ 's answers

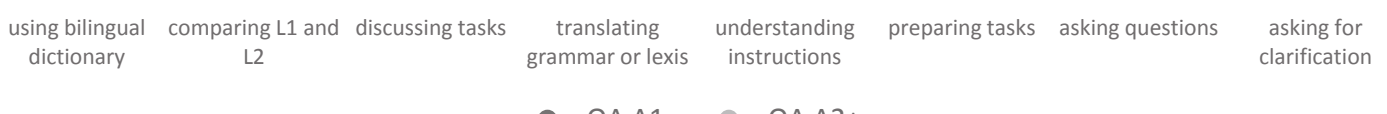

Figure 4. The number of responses regarding teachers' opinions on OAs'experience of using L1

Table 3. The overall percentage of students' and teachers' experiences

\begin{tabular}{|l|c|r|c|}
\hline \multicolumn{1}{|c|}{$\%$} & OA A1 & ET A1 & IT A1 \\
\hline using bilingual dictionary & $\mathbf{1 0}$ & $\mathbf{1 1}$ & $\mathbf{1 2}$ \\
\hline comparing L1 and L2 & 5 & 14 & 11 \\
\hline discussing tasks & 5 & $\mathbf{1 4}$ & $\mathbf{1 6}$ \\
\hline translating grammar or lexis & 24 & 11 & 14 \\
\hline understanding instructions & 19 & 9 & 7 \\
\hline preparing tasks & 0 & 9 & 14 \\
\hline asking questions & 5 & $\mathbf{1 4}$ & $\mathbf{1 4}$ \\
\hline asking for clarification & 33 & 18 & 12 \\
\hline
\end{tabular}

\begin{tabular}{|l|c|r|c|}
\hline \multicolumn{1}{|c|}{$\%$} & OA A2+ & ET A2+ & IT A2+ \\
\hline using bilingual dictionary & 19 & 15 & 9 \\
\hline comparing L1 and L2 & 24 & 15 & 9 \\
\hline discussing tasks & 5 & $\mathbf{1 5}$ & $\mathbf{1 5}$ \\
\hline translating grammar or lexis & 24 & $\mathbf{1 2}$ & $\mathbf{9}$ \\
\hline understanding instructions & 10 & 15 & 19 \\
\hline preparing tasks & 5 & 15 & 11 \\
\hline asking questions & $\mathbf{5}$ & $\mathbf{5}$ & $\mathbf{1 3}$ \\
\hline asking for clarification & $\mathbf{1 0}$ & $\mathbf{1 0}$ & \\
\hline
\end{tabular}

Source: Own research 
The answers to the questions regarding older learners' actual experiences connected to the use of L1 in the classroom are particularly intriguing. Unlike in case of the previous group of questions which referred directly to students' needs, the answers provided by the students in the second part of the questionnaire reflect actual teaching and learning practice taking place in the classrooms. Yet, this part proved to be the most diverse of all. In the case of the lower level A1, students' and teachers' answers were similar when referring to "using bilingual dictionaries" only -10, 11 and $12 \%$, and in case of the higher level A2+ "asking for clarification" - 10, 10 and 13\% were the answers of the respondents, and "asking questions" 5 and $5 \%$ were the answers of the students and experienced teachers.

The question arises why are all of the remaining results so different? One might argue that it is nearly impossible for the inexperienced teachers to anticipate what students do in class, but this is certainly not true in case of the experienced group. Moreover, both groups of teachers responded similarly to some of the questions and their answers stood in opposition to students' answers. For instance, asking questions (A1) and discussing tasks (A2+) were chosen by both groups - 14 and 15\%, respectively, while students rarely chose these answers $-5 \%$ in both cases. Similarly, discussing tasks was ticked by the teachers more often - 14 and 16\% - while students did not prefer this answer - once again only $5 \%$ of them decided that it's important. The opposite was true in case of the higher level A2+ where students decided that translating grammar is one of the most important moments when they resort their L1 during the lesson - $24 \%$ of the answers, as in case of comparing L1 and L2, whereas the teachers believed that it is less important than, for instance, understanding instructions and discussing tasks (19 and 15\% ITs) or using bilingual dictionary, comparing L1 and L2, discussing tasks, understanding instructions and preparing tasks, each of which amounted to $15 \%$ of the answers.

Such dissimilarities, which are visible in students' and teachers' answers, prove that whether experienced or not teachers seem to have a completely different view of what should be taking place in the classroom and how often their students would like to allow for own-language use. In fact, as Włosowicz (2016) points out, "the older learners are still accustomed to the grammar-translation method" and therefore might expect more help from their mother tongue as otherwise it can influence their confidence.

III. The third part of the questionnaire is intended to present OAs' own opinions regarding the use of L1 and the juxtaposition with teachers' views regarding the matter.

The figures presented in the graphs below illustrate students' feedback to the following questions:

What is your opinion on the usage of L1? 
Journal of Education Culture and Society No. 2_2016

1. Does the use of L1 increase your learning capacity?

2. Does the use of L1 make you feel more confident?

3. Do you think that using L1 helps you to understand?

4. Do you think that you find code-switching enjoyable?

5. Do you think that you find code-switching practical?

6. Do you think that you find code-switching useful in real-life context?

7. Do you think that you find rehearsing their speeches in L1 useful?

$\mathrm{OA} \mathrm{A} 1$ and $\mathrm{A} 2+$

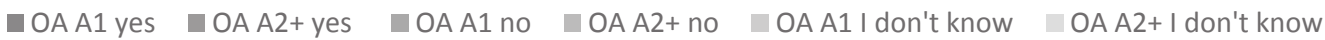

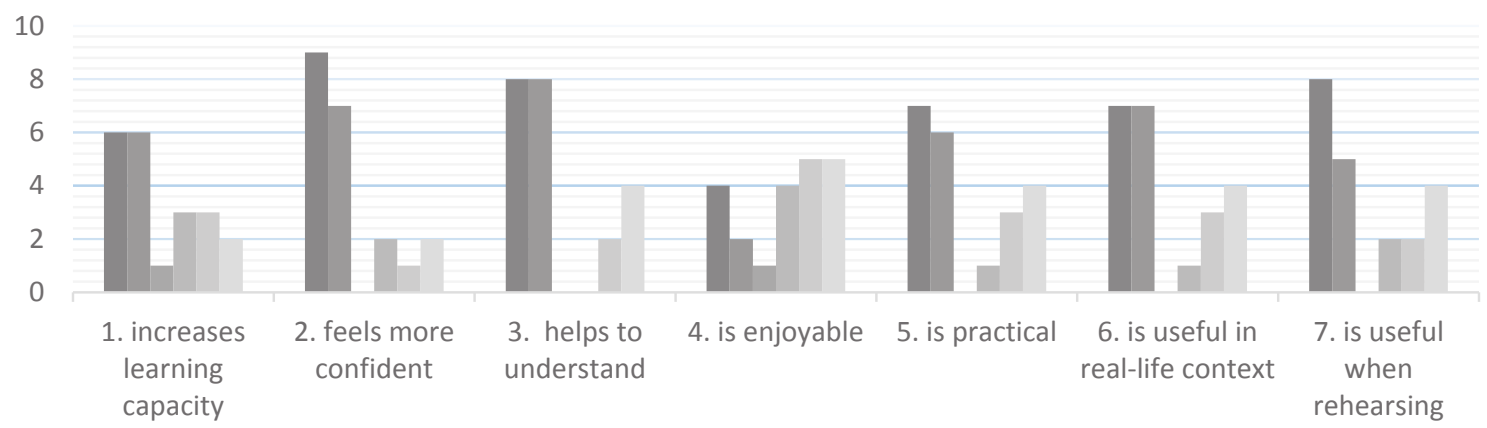

Figure 5. Older adult learners' beliefs on the use of L1

What do you think is your students' opinion on the usage of L1?

OA $A 1$ and $A 2+I T ' s$ answers

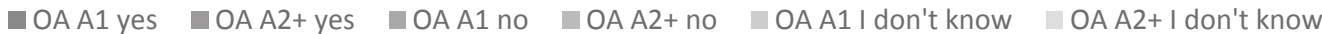

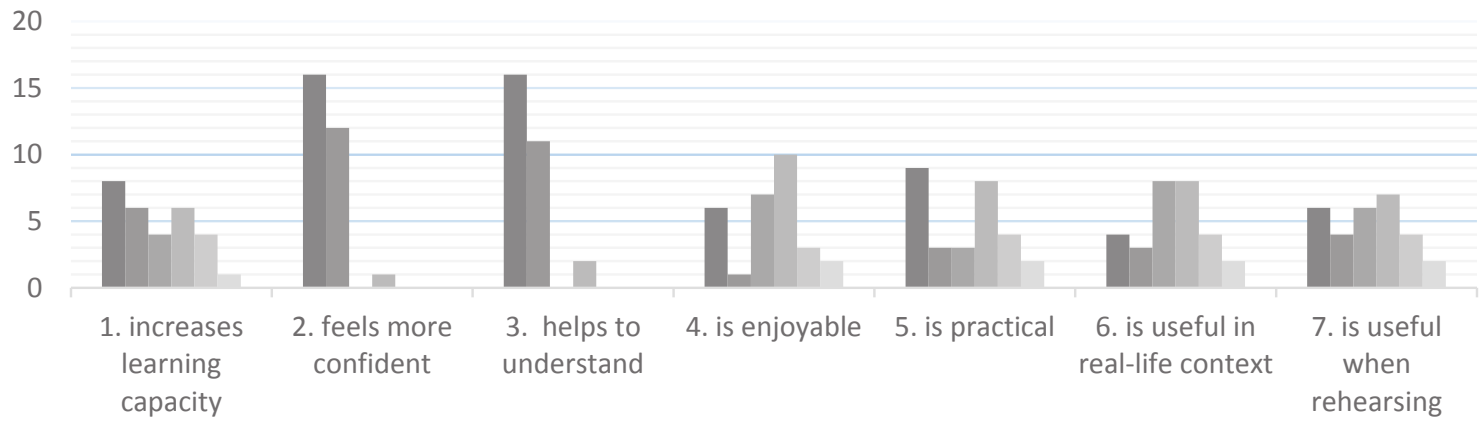

OA A1 and A2+ ET's answers

-OAA1 yes $\square \mathrm{OAA} 2+$ yes $\square \mathrm{OAA} 1$ no $\square \mathrm{OAA} 2+$ no $\square \mathrm{OAA} 1$ I don't know $\square \mathrm{OAA} 2+$ I don't know

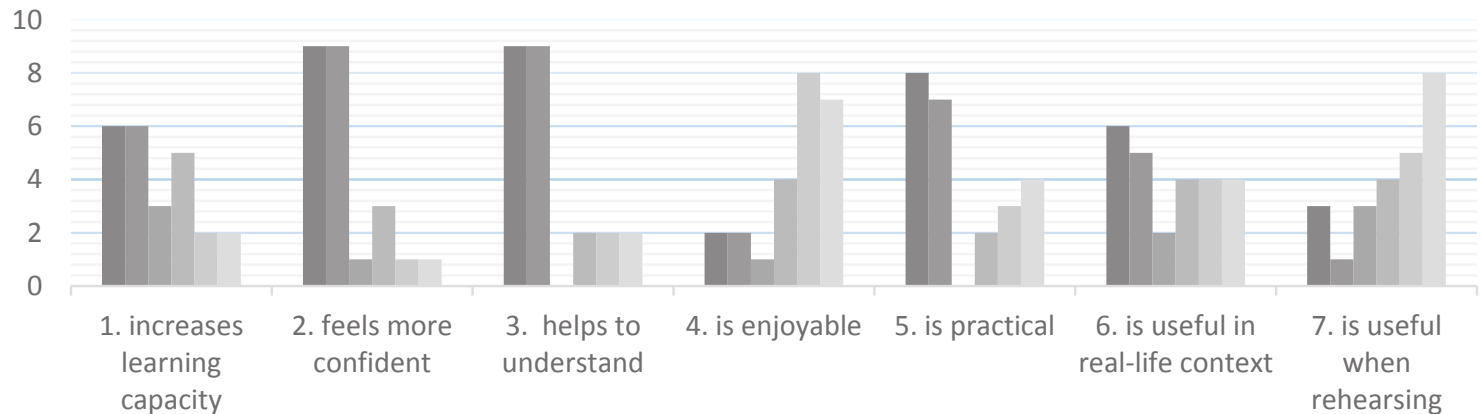

Figure 6. Teachers'opinions regarding OAs' beliefsof the use of L1 
Table 4. The overall percentage of students' and teachers' beliefs

\begin{tabular}{|l|l|l|l|}
\hline \multicolumn{1}{|c|}{$\%$} & OA A1 & ET A1 & IT A1 \\
\hline & & & \\
\hline yes & 70 & $\mathbf{5 5}$ & $\mathbf{5 8}$ \\
\hline no & 3 & 13 & 25 \\
\hline I don't know & $\mathbf{2 7}$ & $\mathbf{3 2}$ & 17 \\
\hline \multicolumn{1}{c}{$\%$} & OA A2+ & ET A2+ & IT A2+ \\
\hline yes & 52 & $\mathbf{4 3}$ & $\mathbf{4 4}$ \\
\hline no & $\mathbf{1 6}$ & 26 & 46 \\
\hline I don't know & $\mathbf{3 1}$ & $\mathbf{3 1}$ & 10 \\
\hline
\end{tabular}

Source: Own research

The answers to the third part of the questionnaire are, once again, in most cases not unanimous, especially while looking at the overall results. Both groups of older adult students believe that using mother tongue in the classroom makes them feel more confident ( 9 and 7 responses) and helps to understand (in both groups 8 responses). Similarly, both groups also believe that it is useful in real life context ( 7 answers in each group), which is pointed to by Clanfield and Foord (2003), who claim that own-language use in the classroom "is likely to be authentic in the sense that it reflects the natural interplay of L1 and L2 which is inherent in second language acquisition" (1). Older adult students also expressed the need to resort to their mother tongue while rehearsing ( 8 and 5 responses in groups $\mathrm{A} 1$ and $\mathrm{A} 2+$ ) and claim that they find it practical ( 7 and 6 responses).

The group of experienced teachers recognise their students' need to use L1 more that the group of inexperienced teachers. Even though both groups of teachers agree that older adults' confidence is significantly raised when they use their mother tongue (IT/ET A1 16/ 9and A2+ 12/ 9 answers, respectively) and it makes the process of understanding easier (IT/ ET A1 16/ 9, and $A 2+11 / 9$ ), they disagree in most other cases. In fact, the most inexplicable is the statement that own-language use can be beneficial when rehearsing (which was rather crucial to the OAs) to which the experienced teachers responded that they do not know (5 and 8 responses) or even that it is not ( 3 and 4 answers), with only 3 and 1 remaining votes pointing to the positive aspects of rehearsal. This is particularly unusual as during the experimental lessons students decided to choose their L1 in most cases when preparing and discussing different tasks, which, as pointed out by Atkinson, can "help [the students to] organize their ideas or choose a more precise lexical item to explain their thoughts to the class or the teacher [...] and can become a vehicle for learning and enforcing language and vocabulary because students are drawing on each other's knowledge" (as cited in Cunningham 2000, p. 3).

The overall results also prove that the experienced teachers better anticipate their students' opinions, but only in case of the "I don't know" answer, which is the only indefinite and unfortunately inconclusive response. Both groups of teachers recognise the need to use L1 in class but it is much lower 
than what is expected of them by the students (55 and $58 \%$ of the teachers' answers and $70 \%$ of the students' responses in the lower group, and 43 and $44 \%$ to $52 \%$ in the higher group). What is crucial, is also the fact that only $3 \%$ of all of the lower level and 16\% of the A2+ OA students do not believe that own-language use can facilitate the process of learning. This in particular shows that teachers belittle the importance of the use of L1 especially in case of older adult learners.

\section{CONCLUSIONS}

According to Park (2000) "[...] psychology has identified four main areas of cognition in which older adults differ from younger adults: sensory function, inhibitory control, working memory capacity (WMC), and processing speed" (as cited in in Cox p. 93). Whereas, McDaniel, Einstein, \& Jacoby (2008) add that the stereotype that "older adults are unable to remember new information can increase anxiety in an instructional context, thus further inhibiting performance" (as cited in Cox, p. 93). All of these five factors have an important influence on the way in which older adults learn as, "sensory function is necessary for perceiving aural and visual input, inhibitory control is important for focusing on helpful information and ignoring distractions, WMC is essential for maintaining information from multiple stimuli, and processing speed determines learner's swiftness in taking in new information and applying to new scenarios" (Cox, p. 94). Moreover, older adult learners who take part in intellectually engaging activities are less likely to show any "cognitive change in their learning abilities, regardless of their level of education" (Hultsch, 1998, p. 280).

Indeed, there are many significant differences between younger and older adults also regarding their learning habits, needs and expectations, but what remains unchanged is the ability to learn and continue one's intellectual development. There are many methods and teaching techniques which can facilitate the process of learning, one of which is own-language use in the language classroom. Often being accustomed to the grammar-translation method, older adult learners feel more comfortable when they can resort to their mother tongue, which seems to be overlooked or ignored by many teachers. Ever since the popularity of GM method has declined, teachers worldwide started to avoid translation at all costs. However, as can be seen from the survey many learners still expect their mother tongue to be used in class. Teachers, on the other hand, do anticipate that need but more rarely and rather less enthusiastically than their elderly students.

As indicated by the results, there were some similarities between students' and teachers' responses but there were also significantly more differences between the answers provided by all of the subjects taking part in the survey. On the whole, older adult students express the need to use their mother tongue in the classroom more often that it is recognised by both groups of 
teachers. The group of inexperienced teachers often seem to be more favourably inclined towards own-language use than the teachers who already have some experience in teaching and are more strict. However, while overlooking older adult students' need to resort to their L1 teachers may make their process of learning more difficult and stressful. Older adults believe that using their mother tongue can facilitate their learning. At the same time own-language use helps to "translate [...] between languages and cultures" (Kerr, 2011), can "promote guessing strategies amongst students and help reduce the word-for-word translation that often occurs and which results in inappropriate L2 use" (Atkinson; after Cunningham 2000, p. 3) and "plays a crucial role in establishing [people's] identity; it should be neither neglected nor subordinated to any other language" (Murakami 2001). Therefore, a more thorough research into older adult learners' needs, expectations and beliefs is necessary in order to better the quality of the learning and teaching this group of students, who would also benefit from some formal training in teaching this group of learners.

\section{REFERENCES}

[1] Atkinson, D. (1987). The mother tongue in the classroom: a neglected resource? ELT Journal, 41(4), 241-247.

[2] Alexander, L. (1987). The use of mother tongue in class. Practical English Teaching, 7(3).

[3] Brown, Ch. (1985). Requests for specific language input: differences between older and younger adult language learners. In: S. M. Gass, \& C. G. Madden (Eds.), Input in Second Language Acquisition (pp. 272-281). New York: Newbury House.

[4] Clanfield, L., \& Foord, D. (2003). Using L1 in the classroom. Retrieved from www.hltmag. co.uk/jan03/martjan032.rtf.

[5] Cook, G. (2010). Translation in Language Teaching. Oxford: OUP.

[6] Cook, V. (1999). Going beyond the native speaker in language teaching. TESOL Quarterly, 33(2), 185-209.

[7] Cox, J. (2014). Older adult learners and SLA: age in a new light. In: C. Sanz, B. Lado, \& S. K. Bourns (Eds.), AAUSC 2013 Volume - Issues in Language Program Direction (pp. 90-107). Australia: Wadsworth.

[8] Cunningham, C. (2000). Translation in the classroom: a useful tool for second language acquisition. ELT Journal, 4(2).

[9] Davies, M. G. (2002). Humanizing translation activities: tackling a secret practice. HLT Magazine, 4(4).

[10] Dench, S., \& Regan, J. (2000). Learning in later life: Motivation and impact. Great Britain, Department for Education and Employment.

[11] Edge, J. (1986). Acquisition disappears in adultery: interaction in the translation class. ELT Journal. 40(2), 121-124.

[12] Hall, G., \& Cook, G. (2013). Own language use in ELT: exploring global practices and attitudes. ELT Journal, 1-48.

[13] Heltai, P. (1989). Teaching vocabulary by oral translation. ELT Journal, 43(4).

[14] Homstad, A. (1987). Neurolinguistic and psycholinguistic research on learning modes of older language learners: classroom implications. Hispania, 70(2), 374-380.

[15] Hultsh, D. F., Hertzog, C., Dixon, R. A., \& Small, B. J. (1998). Memory change in the aged. Cambridge: CUP.

[16] Jaroszewska, A. (2013a). Nauczanie jezzyków obcych seniorów w Polsce [Seniors foreign language teaching in Poland]. Kraków: Impuls.

[17] Jaroszewska, A. (2013b). Gdzie, jak i dlaczego polscy seniorzy uczą się języków obcych? 
[Where, how and why polish seniors learn foreign languages]. Jezzyki Obce w Szkole, 4, 89-94.

[18] Kerr, P. (2011). Translationhandout. Retrieved from https://translationhandout.wordpress. com.

[19] Klimczuk, A. (2012). Kapitał społeczny ludzi starych na przykładzie mieszkańców miasta Biatystok [The social capital of older people on the example of the inhabitants of Bialystok]. Lubin: Wiedza i Edukacja.

[20] Levine, G.S. (2014). Principles for code choice in the foreign language classroom: a focus on grammaring. Language Teaching, 47(03), 332-348.

[21] Murakami, M. (2001). The bridging strategy: active use of learners first language in second language teaching. HLT Magazine, 3(6).

[22] Murphy, B. (1988). Teaching translation and teaching through translation. MET, 15(4).

[23] O'Keeffe, R. (2011). Towards a principled use of L1 in the classroom: a systematic approach. Humanising Language Teaching, 13(5).

[24] Oxford-Carpenter, R. (1985). A New Taxonomy of Second Language Learning Strategies. Washington DC: ERIC Clearinghouse on Languages and Linguistics.

[25] Patkowski, M. (1982). The sensitive period for the acquisition of syntax in a second language. Child-adult differences in second language acquisition. Rowley, MA: Newbury House.

[26] Richards, J. C., Rogers, T. (1986). Approaches and methods in language teaching. Cambridge: CUP.

[27] Salthouse, T.A. (1988). Aging and psychometric tests of verbal ability. Language, Memory and Aging. Cambridge, UK: Cambridge UP.

[28] Sampson, A. (2012). Learner code-switching versus English only. ELT Journal, 66(3), 292-303.

[29] Schulz R. A., Elliot P. (2000). Learning Spanish as an older adult. Hispania, 83(1), 107-119.

[30] Singleton, D. \& Ryan, L. (2004). Language Acquisition: The Age Factor. Clevedon: Multilingual Matters.

[31] Słowik, A. (2016). Adult Learners and the Use of L1 in the Foreign Language Classroom. Anglica Wratislaviensia, 54. [in print].

[32] Snow, C. E. \& Hoefnagel-Höhle, M. (1978). The Critical Period for Language Acquisition: Evidence from Second Language Learning. Child Development, 49(4), 1114-1128.

[33] Titford, C. \& Hieke, A. E. (1985). (Eds.) Translation in foreign language teaching and testing. Tubingen: Gunter NarrVerlag.

[34] Vermes, A. (2010). Translation in foreign language teaching: a brief overview of pros and cons. Eger Journal of English Studies, X, 83-93.

[35] Weinstein-Shr, G. (1993). Growing old in America: learning English literacy in the later years. ERIC Digest. Washington DC: National Clearinghouse for ESL Literacy Education.

[36] Wilson, J. J. (2008). How to Teach Listening. Edinburg Gate: Pearson Education Ltd.

[37] Włosowicz, T. M. (2016). Adult Learners Expectations Concerning Foreign Language Teachers and the Teaching-Learning Process. In: D. Gabryś-Barker, \& D. Gałajda (Eds.), Positive Psychology Perspectives on Foreign Language Learning and Teaching (pp. 267-288). Switzerland: Springer. 


\section{Appendix 1}

PART I - ABOUT YOU (an interview)

1. Age group:

2. Sex:

$50+$

Man

Woman

3. Your English language level:

4. beginner $\square$ pre-intermediate

5. Type of school in which you study English: private $\square$ public

6. What is your occupation?

7. How long have you been studying English for?

8. In which country do you study English?

9. What is your mother tongue?

10. Why do you study English?

11. How often do you use your LI in class: always $\square$ usually $\square$ often other (please specify)

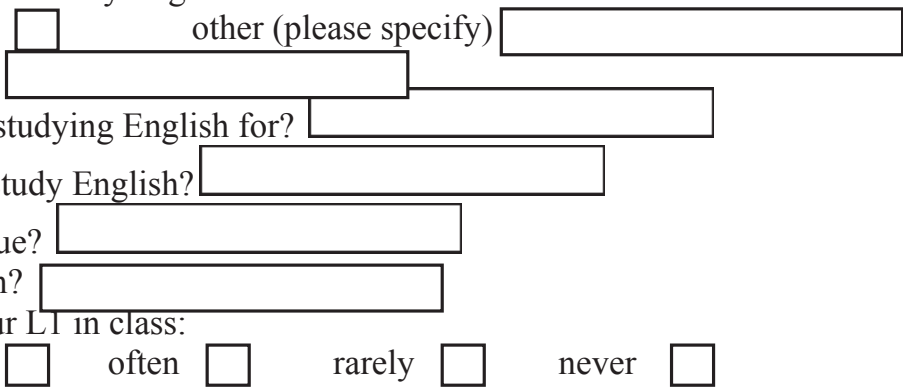

PART II - ABOUT YOUR CLASSES (a questionnaire)

I. When would you like your L1 to be used in class?
1. To explain vocabulary
2. To give instructions
3. To explain grammar
4. To correct spoken errors
5. To explain when meanings in English are unclear
6. To give feedback on written work
7. To test and assess
8. To maintain discipline
9. To develop rapport
always/usually/often/rarely/never always/usually/often/rarely/never always/usually/often/rarely/never always/usually/often/rarely/never always/usually/often/rarely/never always/usually/often/rarely/never always/usually/often/rarely/never always/usually/often/rarely/never always/usually/often/rarely/never

II. When do you use your L1 in class?

1. Check words in a bilingual dictionary

2. Compare English grammar to the grammar of your own language

3. Discuss tasks with your partner

4. Translate difficult grammar or lexis always/usually/often/rarely/never

5. Prepare for tasks and activities in your

own language before switching to English always/usually/often/rarely/never

6. Make sure you understand the instructions

7. Ask questions

8. Ask for clarification

always/usually/often/rarely/never always/usually/often/rarely/never always/usually/often/rarely/never

always/usually/often/rarely/never always/usually/often/rarely/never always/usually/often/rarely/never

III. What is your opinion on the use of L1?

1. Does the use of L1 increase your learning capacity?

2. Does the use of L1 make you feel more confident?

3. Do you think that using L1 helps you to understand?

4. Do you find code-switching enjoyable?

5. Do you find code-switching practical?

6. Do you find code-switching useful in real-life context?

7. Do you think rehearsing your speeches in L1 is useful?

$$
\begin{aligned}
& \text { yes/no/ I don't know } \\
& \text { yes/ no/ I don't know } \\
& \text { yes/ no/ I don't know } \\
& \text { yes/ no/ I don't know } \\
& \text { yes/ no/ I don't know } \\
& \text { yes/ no/ I don't know } \\
& \text { yes/ no/ I don't know }
\end{aligned}
$$

(based on a questionnaire designed by Graham Hall \& Guy Cook, "Own Language Use in ELT: Exploring Global Practices and Attitudes." ELT. 1-48.) 